$1969-70$ to $£ 2.85$ million. Licence income from patents, the corporation's biggest source of income amounted to $£ 3.7$ million, of which $£ 2.7$ million were foreign currency earnings. The drug cephalosporin $\mathrm{C}$ was again the largest revenue earner.

Submissions of new projects for support rose from 2,194 to 2,535 , but the numbers presented by the universities and industry both fell, the increase coming from submissions by private inventors. The corporation felt that the fall in applications from industry was "a possible reflexion of the cutting back of research and development by firms encountering cash flow difficulties". Commenting on this Dr Bard said that he was convinced this was "only a hiccup" in the growth of research and that it would be "the greatest mistake at the present time to cut down on research and development".

\section{RESEARCH AND DEVELOPMENT}

\section{Small Firms Feel Pinch}

A REPORT on Scientific and Engineering Manpower and Research in Small Firms (HMSO, 40p), published last week, concludes that the use of scientific and technical personnel in small companies may be linked to the capital intensiveness of the industry concerned.

The report, one of the research studies commissioned by the Bolton Committee of Inquiry on Small Firms, sets out to examine the degree to which small companies - those with between eleven and 200 employees-are in a position to benefit from, and contribute to, the technological advance of British industry.

The report shows that small companies employ about a third $(2.5 \mathrm{mil}$ lion) of all employees in manufacturing industries, but only 15.5 per cent of the equivalent of graduate qualified engineers, technologists and scientists (QSEs). (Figures are for 1968.) This is a proportion of QSEs to other employees of 0.7 per cent, only half that of larger companies. The distribution within small companies is not even, but small electronics companies alone have a higher proportion of QSEs than their larger competitors. The proportion of QSEs in small electronics companies is higher than in other small companies because research in electronics is a rapidly advancing technology at a highly theoretical as well as a purely practical level, and because "materials are relatively inexpensive and large capital facilities are unnecessary". Innovation in fields such as mechanical engineering requires a bigger "technological step" and large expenditure on the trial and testing of new products.

This led to the conclusion that capital-intensiveness may be the key to
QSE employment in small companies, and the observation that many small companies rely on contracts with outside laboratories for their research work as this limits the extent of their expenditure and removes the necessity of maintaining their own full-time research facilities.

The expected growth rate for small companies from 1968-71 was 27.1 per cent compared with 20.9 per cent for all companies. If the report's suspicions about a "technological step" are right, then this "implies a barrier to greater employment of QSEs and further technological advance".

\section{MUSEUMS \\ Timbers to Greenwich}

THE National Maritime Museum (NMM) at Greenwich is advertising for an archaeologist to be appointed at the relatively elevated rank of Assistant Keeper. This is certainly novel, and may be thought bizarre, but it is the direct result of the archaeological "rescue" of the Graveney boat unearthed in Kent salt marshes last October (Nature, 228, 402; 1970) and since then carbon-dated by the British Museum as late ninth century.

The new director of the museum, $\mathrm{Mr}$ Basil Greenhill, has a number of sweeping plans for a new look for the NMM and one of them is to extend the exhibition of boats on display. Apart from the Cutty Sark nearby, the museum has relied on its superb collection of contemporary models and numerous fine marine paintings to demonstrate the art of shipbuilding. At present its largest gallery, the Victorian Neptune Hall, is being converted to accommodate boats of different periods, not all of them small, such as the 1900 paddlewheel tug Reliant whose fore-end including the bridge and engine room will form the centrepiece of the display when the hall is reopened next year. The opportunity of adding a preConquest boat to the group was too good to miss although, by any estimate, the Graveney boat is no beauty.

Very considerable expertise is required to derive the full information retained in the lines and timbers of an antique vessel especially when it is sodden with salt water. The expectation is that the successful candidate, whether his or her training is in archaeology, anthropology or naval architecture, will have to acquire a number of other special skills. There is nowhere to train in the field of nautical archaeology, so the unit's archaeologist will have to resort to self-improvement. Besides looking to the eventual display of the original Graveney boat in Neptune Hall, there is a plan to build a replica and row it across the North Sea as the Anglo-Saxons did when they journeyed between Kent and the Continent. Altogether some $£ 50,000$ has been committed to this unit.

Once the unit is in existence it will obviously do more than simply process the Graveney boat; a committee of experts will screen other candidate timbers or craft for treatment and preservation. This will provide a unique facility for Britain. There are few other places in the world where waterlogged wood up to 50 foot long can be handled. Will there be a rush of old timbers to Greenwich? One thing is clear-the line is being drawn at boats, and specifically boats less than 50 foot long. There is no possibility that the eighteenth century East Indiaman, Amsterdam, buried at Hastings, or Henry V's Grace Dieu, still in the mud of the Hamble river, will be imported to the Greenwich tanks.

\section{EDUCATION \\ Computing in Schools}

THE view that teacher training is the most urgent need in the expansion of computer science teaching in secondary schools is put forward in a report of an international seminar held in Sevres during March, 1970 (Computer Sciences in Secondary Education, OECD, Paris; $1971 ; £ 1.90$ ).

The report, like the papers presented at the six-day meeting, recognizes the need for several types of school computing course, which could be taught by teachers with quite different educational backgrounds. These include appreciation courses which require almost no computer time and could, in principle, be taught by any numerate teacher, and other courses which contain more instruction in programming and in the working of computers; these would have to be taught by mathematicians or scientists. Ultimately, says the report, the aim should be to include at least a computer appreciation course in all secondary school teacher training.

Much of the seminar was taken up with discussions of the significance and objectives of the teaching of computer science in schools. There was agreement that one of the important functions of computer education is the encouragement of skills in organizing and handling information, which are useful in the study of most subjects and which help to convince pupils that information is a means to an end but not an end in itself.

Even the simplest appreciation course requires a certain amount of access to a computer, if the subject is not to appear to be too abstract, and the report suggests that agreements should be encouraged which allow pupils' pro- 